\title{
The Importance of Discourse Studies in Linguistics, Language Teaching and Translation
}

\author{
Daniel Rodríguez-Vergara \\ National Autonomous University of Mexico, Mexico City, Mexico
}

\begin{abstract}
One of my purposes was to listen, to hear speech, accent, speech rhythms, overtones, and emphasis. For speech is so much more than words and sentences.
\end{abstract}

(John Steinbeck)

In this paper, I explain the importance that discourse studies have had in the general field of linguistics, and in the specific branches of language teaching and translation, respectively. In order to show part of the knowledge that linguists have explored through the analysis of discourse, I draw on systemic functional linguistics and the way this theory can be applied in the explanation of language and its relationship to social context. In addition, I use Swales' model of article introductions and Hyland's model of metadiscourse as two examples of discourse methods within the branch of language teaching; in turn, I use both the rhetorical structure and the thematic structure approaches as two proposals of analysis that can be applied in the branch of translation. With those models and approaches to discourse, it has been possible for linguists to analyze authentic texts performed in real contexts.

Keywords: discourse analysis, functional linguistics, English for Academic Purposes, linguistic translation

\section{Introduction}

Although now discourse studies are commonly based on social and functional theories of language, it was Chomsky's teacher, structuralist Zellig Harris, who coined the term “discourse analysis" in 1952, observing that "Language does not occur in stray words or sentences, but in connected discourse-from a one-word utterance to a ten-volume work, from a monolog to a Union Square argument” (Harris, 1952, p. 3). He thus aimed at providing an account of language beyond the limits of the sentence.

Within linguistics, the meaning of the term "discourse" can vary depending on the context in which it is used, but two main definitions can be identified. One is provided by Harris (1952), viz., the level of language above the sentence; and the other, advocated by Brown and Yule (1983), refers to language in use, including its forms, purposes, and functions. From a social point of view, we actually do things with language: fundamentally, construe experience and interact with people (Halliday \& Matthiessen, 2014). Taking into account the fact that language is a social and functional phenomenon, discourse studies have had a significant contribution to the

Daniel Rodríguez-Vergara, Ph.D., associate professor, Department of Applied Linguistics, National Autonomous University of Mexico, Mexico City, Mexico. 
general study of language. In the following section, I will explain the importance of discourse studies in linguistics. Later, I will refer to the specific contribution of discourse studies to language teaching and translation, respectively.

\section{The Importance of Discourse Studies in Linguistics}

Linguists have gained a considerable understanding of the way language works by looking at real, authentic discourse and its relationship to context. Within the applied dimension of linguistics, McCarthy, Matthiessen, and Slade (2010, p. 54) point out that "The important position that discourse analysis occupies in applied linguistics has come about because it enables applied linguists to analyze and understand real language data”. The language data that applied linguists analyze can be either written or spoken, and one thing they have learned through the analysis of discourse is that spoken language is no less structured than written language.

From a functional point of view, both speech and writing have linguistic complexity, albeit of a different kind. Consider the following three ways of expressing more or less the same meanings (taken from Halliday, 1997/2004, p. 196):

(i) the use of this method of control unquestionably leads to safer and faster train running in the most adverse weather conditions

(ii) if this method of control is used trains will unquestionably be able to run safelier and faster even when the weather conditions are most adverse

(iii) you can control the trains this way and if you do that you can be quite sure that they'll be able to run safelier and faster no matter how bad the weather gets

Example (i) is typical of a written formal text, (iii) is its spoken informal version, and (ii) is somewhere in the middle. Example (i) has 12 lexical items (content words, which are underlined), (ii) has 11, and (iii) has eight. On the other hand, example (i) has one clause, (ii) has three, and (iii) has five (whose verbs are in bold). Therefore, the written version has the highest lexical density (12, which is the number of lexical items divided by the number of clauses). However, the spoken version has the highest grammatical intricacy (five, which is the number of clauses per clause complex). Thus, as Halliday (1989) states, whereas the complexity of writing is in its lexis, the complexity of speech is in its grammar.

In discourse studies, it has been important to determine the way formal written texts achieve density and abstraction. Systemic functional linguists (Halliday \& Matthiessen, 1999; 2014) have found that one way is through the use of ideational grammatical metaphor, which refers to the nominalization of clauses. For example, the noun group of example (i) above, the use of this method of control, is the nominalization of the clause this method of control is used. Complex nominal forms such as the one in (i) are considered metaphorical because they appear later than the clausal forms both in the language development of individuals (ontogenesis) and in the history of scientific texts (phylogenesis).

Besides making such an important connection between spoken and written language, by considering texts and not sentences as fundamental units of analysis, discourse studies have been able to examine genres used by different speech communities. Discourse genres have been studied from multiple perspectives, e.g., literary (Bakhtin, 1986), English for Academic Purposes (EAP) (Swales, 1990), rhetoric (Bazerman, 1997), and systemic 
functional (Martin \& Rose, 2008). From the systemic functional perspective, genre is defined as "a staged, goal-oriented social process. Social because we participate in genres with other people; goal-oriented because we use genres to get things done; staged because it usually takes us a few steps to reach our goals” (Martin \& Rose, 2007, p. 8). Their approach to genre is the result of a comprehensive research project on writing at primary and secondary schools in Sydney. Student writing was analyzed to identify text types used across the curriculum. This was later the basis for the design of literacy programs that have been very successful in the development of academic literacies (Dreyfus, Humphrey, Mahboob, \& Martin, 2016).

According to Martin and Rose (2008), a genre is realized through the context of culture, i.e., through the system of beliefs, values, and ideologies shared by the speech community that uses that genre. In turn, discourse is realized through register, which is defined as a configuration of meanings determined by the three dimensions that constitute the context of situation, viz., field, tenor, and mode of discourse (Matthiessen, Teruya, \& Lam, 2010), as illustrated in Figure 1.

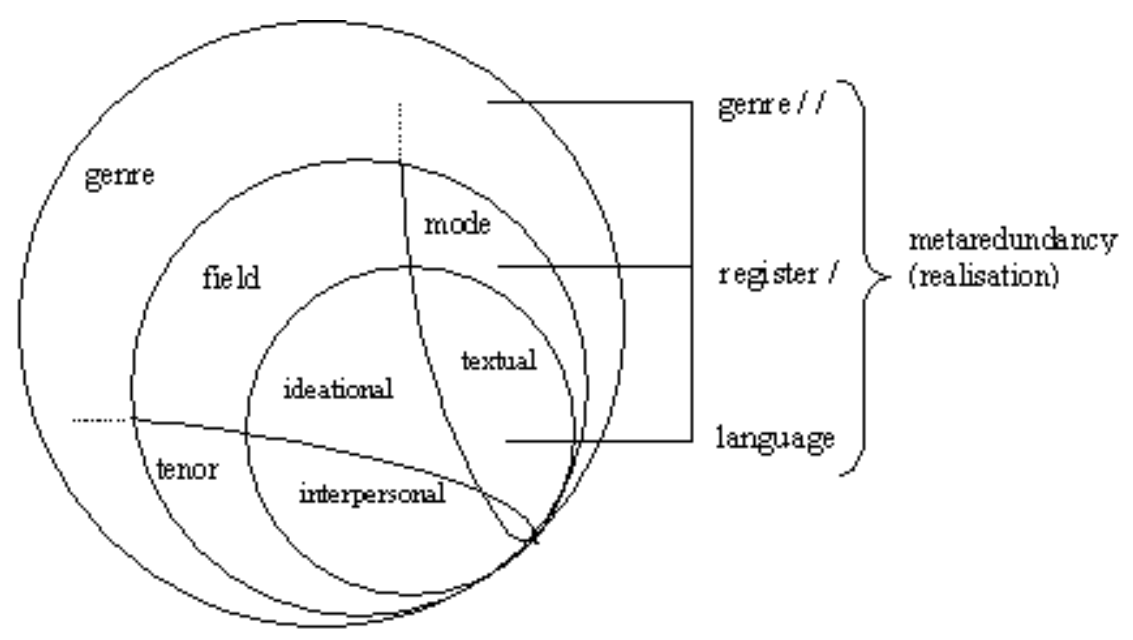

Figure 1. Language, register, and genre (Martin, 1997, p. 189).

Field of discourse refers to the type of social activity that we are doing with language (arguing, explaining, categorizing, chronicling, narrating, etc.) and the domain of experience with which the social activity is related (politics, linguistics, music, cars, books, etc.). Tenor of discourse makes reference to the institutional roles of speakers in a situation (mother-son, teacher-student, colleague-colleague, etc.), their power status among each other (equal or unequal), and their degree of familiarity (close or distant). Finally, mode of discourse alludes to the channel of communication (visual, auditory, tactile), the medium (spoken or written), and the type of turn (monologue or dialogue).

It has been stated that each of the contextual variables both realizes and is realized (metaredundancy correlation) by the type of meanings expressed in texts (see Figure 1). First, field of discourse correlates with ideational meaning, which is used to represent what happens in the world, i.e., events, actions, states, etc. The semantic element that determines the kind of experience that is represented in a clause is the "process", which can be material (doing, changing, creating), relational (being, having, symbolizing), mental (perceiving, thinking, feeling), verbal (saying, asking, demanding), existential (existing), or behavioral (behaving). 
Second, tenor of discourse correlates with interpersonal meaning, which is used to interact with other speakers. Interaction among speakers is defined in terms of speech functions (giving/demanding information/goods and services), expressions of modality (probability, usuality, obligation, inclination), of attitude (emotions and opinions), and of engagement (intersubjective positioning).

The third variable, mode of discourse, correlates with textual meaning, and is concerned with the flow of information and the method of development of thematic and rhematic elements. The following is Halliday and Matthiessen's (2014, p. 89) definition of "theme":

The Theme is the element that serves as the point of departure of the message; it is that which locates and orients the clause within its context. The speaker chooses the Theme as his or her point of departure to guide the addressee in developing an interpretation of the message; by making part of the message prominent as Theme, the speaker enables the addressee to process the message. The remainder of the message, the part in which the Theme is developed, is called in Prague school terminology the Rheme.

Thus, from the point of view of discourse, in clauses, not only grammatical subjects can be identified, but also themes (textual meaning) and the actors that carry out the processes (ideational meaning). In a clause such as Shakespeare wrote the two parts of Othello at different times (Allen, 1968, p. 17), the subject, theme and actor is the same (Shakespeare); but if the author had written his clause as At different times, the two parts of Othello were written by Shakespeare, the subject (the two parts of Othello) would be different from the theme (At different times) and from the actor (Shakespeare). Whether the author chooses to start his clause with the subject or not depends on discursive criteria such as what the author thinks the reader will consider newsworthy information.

The description of the correlation between contextual and semantic variables is a powerful resource that has enabled linguists to deepen their understanding of how discourse is embedded in the social environment. Language is not what people know but what people do, and people cannot do without context. Halliday and Hasan (1989, p. 9) go so far as to say that the success of communication among people is due to the information they get from context: "We make predictions-not consciously, of course; in general, the process is below the level of awareness-about what the other person is going to say next; and that's how we understand what he or she does say". Likewise, register and genre theory enables discourse analysts to make predictions about the types of meanings that are expressed in a text, and conversely, the meanings analyzed in a text enable them to make predictions about the context of production of that text.

\section{Discourse Studies and Language Teaching}

Language teaching/learning and translation are probably two of the most important branches of applied linguistics. Regarding language teaching, Berns and Matsuda (2010, p. 11), in their entry of the term "applied linguistics" in the Concise Encyclopedia of Applied Linguistics, state that:

Although applied linguistics in Europe and North America by and large encompasses more than language learning and teaching, many applied linguists elsewhere continue to be largely concerned with language teaching. Due to globalization of the world's economy and the attendant spread of English and its social values, considerable time, attention and money are devoted to the teaching of English as a foreign or second language.

That many applied linguists are largely concerned with language teaching, especially English, is true at least in the Mexican context. However, it is also true that they have recognized the potential of discourse analysis as a 
tool to investigate, among other things, language teaching (Poole, 2010). In this respect, one of the areas that has fruitfully made a connection between discourse analysis and language teaching is EAP (Jordan, 1997). From this area, two frameworks will be briefly discussed here, which, in my view, depict the importance of discourse studies in language teaching, viz., Swales’ model of article introductions (1981; 1990; 2004) and Hyland's model of metadiscourse (2005).

In the academic context, scholars are increasingly required to write and publish research articles. Also, as explained by Hyland (2009) and Swales (2004), the role of English as a lingua franca generates pressure to write and publish manuscripts in that language: "universities around the world now require staff to present at international conferences and, more crucially, publish in major, high-impact, peer-reviewed Anglophone journals as a prerequisite for tenure, promotion and career advancement” (Hyland, 2009, p. 67). One example of that situation is the Mexican National System of Researchers (in Spanish, Sistema Nacional de Investigadores), where, in order to get research grants, it is necessary to demonstrate significant contributions in research.

However, students often struggle to write research genres such as theses and articles, and the situation is even more complicated when they have to write those genres in English as a foreign language. In particular, attention has been given to the problem of writing research articles by native and non-native speakers of English (Swales, 2004). One source of difficulty is that each part of the article has typically different linguistic and rhetorical characteristics. For example, whereas introduction and discussion sections possess a more discursive and interpretative nature, methods and results sections have a more recounting and reporting style (Fryer, 2012). Thus, because of its rhetorical demands, and because it is the part where writers have to persuade readers that their object of study is legitimate and significant, research article introductions have been extensively studied from the perspective of EAP (e.g., Swales, 1981; 1990; 2004; Bhatia, 1997; Gledhill, 2000; Samraj, 2002).

Swales' model of article introductions emerged out of a need to design appropriate materials to teach students how to write that section (Swales, 1981). The first step was building a corpus of 48 article introductions from three areas, namely, hard sciences, health sciences, and social sciences. According to Swales (1981, p. 22), by far the commonest pattern of "moves" that he observed in the corpus was the following:

1. There was an "opening section" that prepared the ground in a restricted number of ways for the summary of Previous Research about to come.

2. The second part consisted of the DPR itself [Describing Previous Research].

3. Immediately after the DPR — or in a few cases partly embedded within it-there occurred a typically rather short statement that formed a bridge between the DPR and a reference to the current research to be described in the rest of the article. The commonest way of handling this transition was to offer a negative evaluation of the DPR, usually by indicating some gap in research of knowledge.

4. The final part of the introduction introduced the present research either by giving the purpose or by making a preliminary descriptive statement of what was done.

However, in his 1990 book, Swales recognized that certain defects had become apparent in that model, in particular, the difficulty of separating moves 1 and 2, and the restrictive range of options in the final two moves. He therefore presented a revised model (see Figure 2), called “CARS” (Create a Research Space), which has been highly influential so far (even more than his 2014 second revision). 


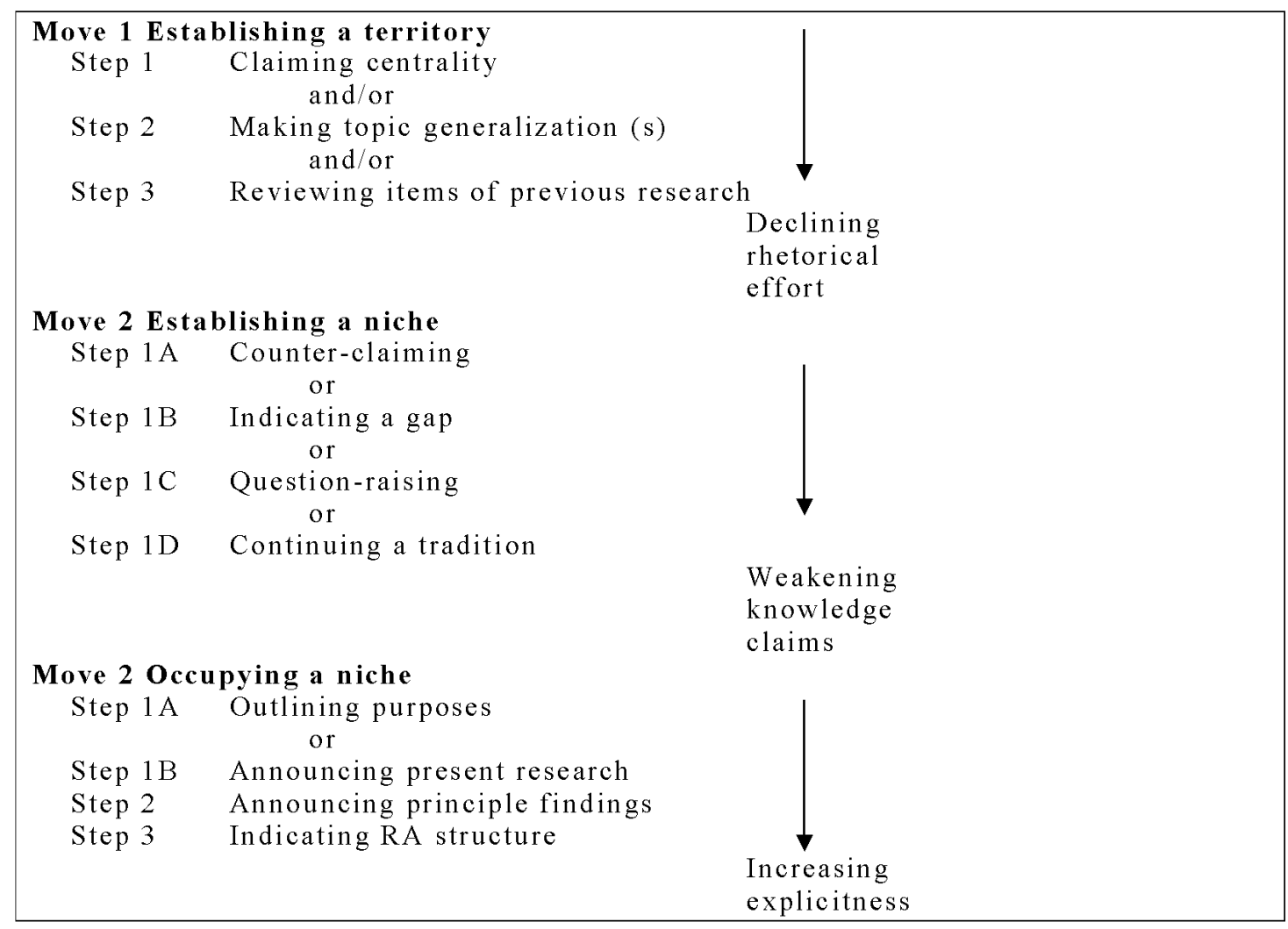

Figure 2. CARS model for article introductions (Swales, 1990, p. 141).

In order to illustrate how this model can be applied to authentic texts, I present in Figure 3 the analysis of the introductory paragraph of Coffin, Hewings, and North's article, from the Journal of English for Academic Purposes (2012, p. 38).

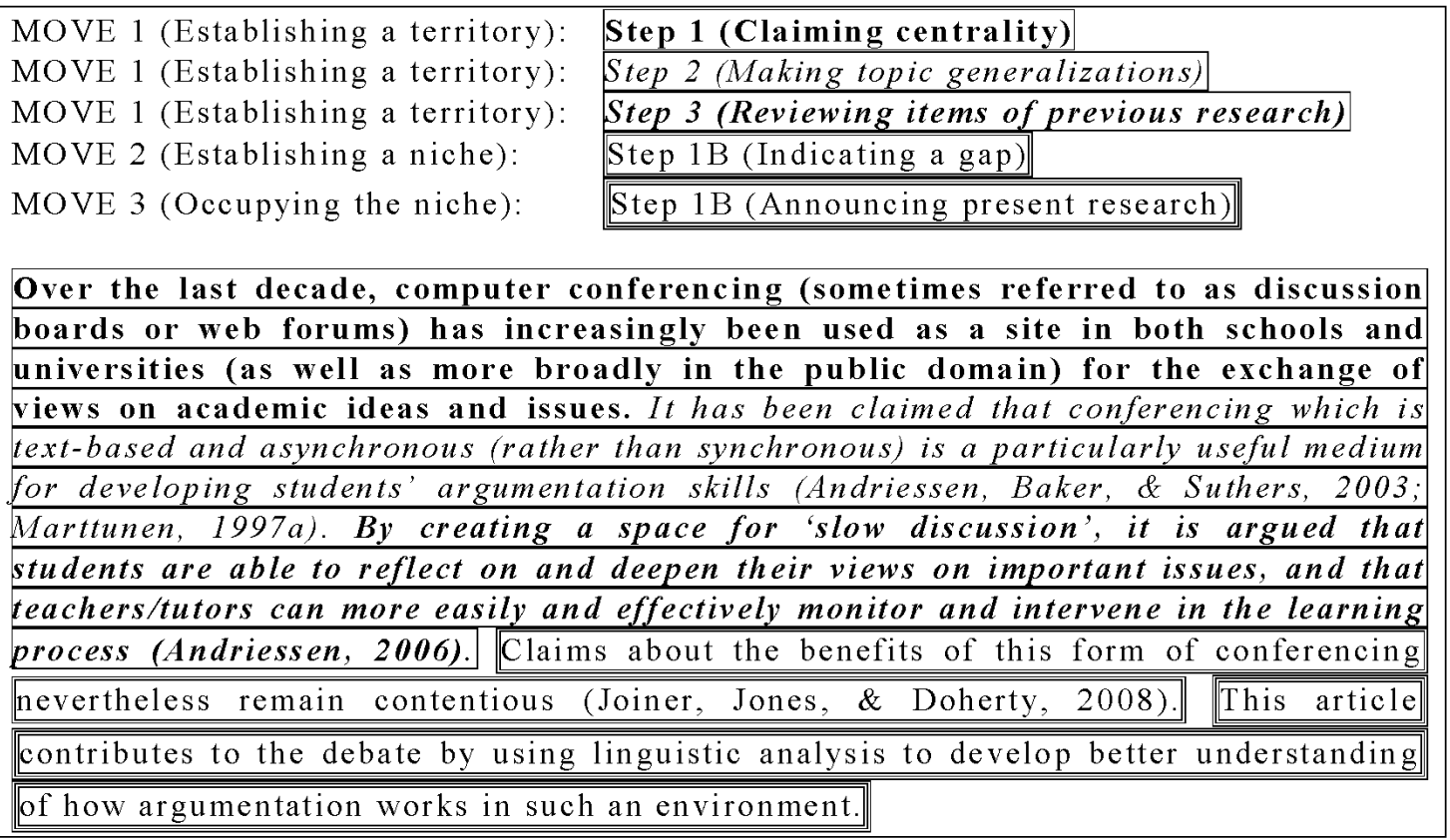

Figure 3. CARS analysis of a research article introduction. 
It is important to mention here that this model is descriptive rather than prescriptive. That is, its intention is to show how things are, not how things ought to be. Likewise, for the purposes of teaching students how to write article introductions, this model should be used as a tool to raise their awareness of the discursive patterns commonly found in articles that have been positively peer-reviewed, and so published. It should not be used as a restrictive formula that restrains creativity (Hyland, 2004, on genre teaching).

The other framework to be discussed here that depicts the importance of discourse studies in language teaching is Hyland's model of metadiscourse (2005) ${ }^{1}$. Hyland (2005, p. 37) defines metadiscourse as "the cover term for the self-reflective expressions used to negotiate interactional meanings in a text, assisting the writer (or speaker) to express a viewpoint and engage with readers as members of a particular community”. Similarly to systemic functional theory (Halliday \& Matthiessen, 2014), this linguistic model emphasizes the interpersonal dimension of language, through which people interact with each other (in both written and spoken texts) and express subjective meanings such as modality, attitude, and involvement.

Based on previous work by Thompson and Thetela (1995), Hyland (2005) divides metadiscursive elements into two categories, namely interactive and interactional. Whereas the former is concerned with ways of organizing information in discourse in view of the expectations writers have about readers, the latter has to do with the expression of axiological and intersubjective meanings. The elements included in each category are presented in Figure 4.

\begin{tabular}{|c|c|c|}
\hline Category & Function & Examples \\
\hline Interactive & Help to guide the reader through the text & Resources \\
\hline $\begin{array}{l}\text { Transitions } \\
\text { Frame markers } \\
\text { Endophoric markers } \\
\text { Evidentials } \\
\text { Code glosses }\end{array}$ & $\begin{array}{l}\text { express relations between main clauses } \\
\text { refer to discourse acts, sequences or stages } \\
\text { refer to information in other parts of the text } \\
\text { refer to information from other texts } \\
\text { elaborate prepositional meanings }\end{array}$ & $\begin{array}{l}\text { in addition; but; thus; and } \\
\text { finally; to conclude; my purpose is } \\
\text { noted above; see Fig; in section } 2 \\
\text { according to X; Z states } \\
\text { namely; e.g.; such as; in other words }\end{array}$ \\
\hline Interactional & Involve the reader in the text & Resources \\
\hline $\begin{array}{l}\text { Hedges } \\
\text { Boosters } \\
\text { Attitude markers } \\
\text { Self mentions } \\
\text { Engagement markers }\end{array}$ & $\begin{array}{l}\text { withhold commitment and open dialogue } \\
\text { emphasize certainty or close dialogue } \\
\text { express writer's attitude to proposition } \\
\text { explicit reference to author(s) } \\
\text { explicitly build relationship with reader }\end{array}$ & $\begin{array}{l}\text { might; perhaps; possible; about } \\
\text { in fact; definitely; it is clear that } \\
\text { unfortunately; I agree; surprisingly } \\
\text { I; we; my; me; our } \\
\text { consider; note; you can see that }\end{array}$ \\
\hline
\end{tabular}

Figure 4. Interpersonal model of metadiscourse (Hyland, 2005, p. 49).

Taking again the introductory paragraph from Coffin et al. (2012) as a sample, in Figure 5 I present the analysis of the metadiscursive elements contained in that fragment.

\footnotetext{
${ }^{1}$ The term “metadiscourse” was coined by structuralist Zellig Harris (1959/1970), who also coined the term “discourse analysis”.
} 


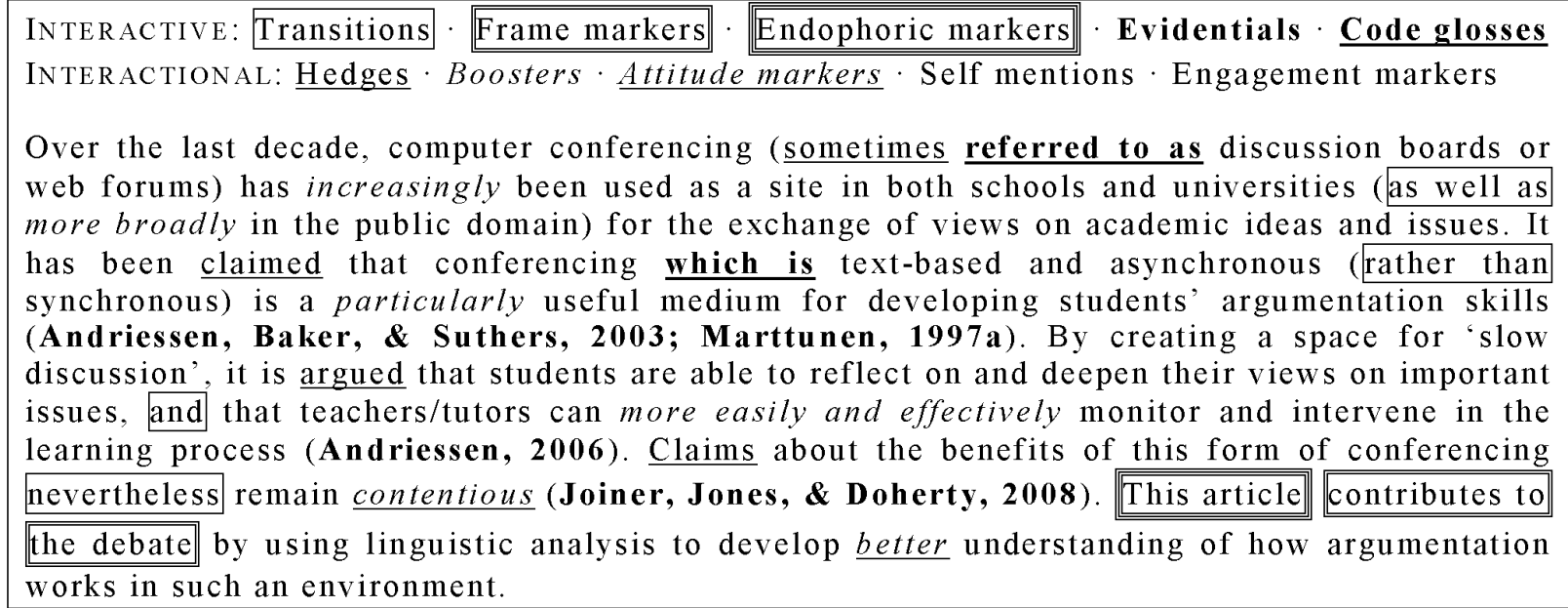

Figure 5. Metadiscurse analysis of a research article introduction ${ }^{2}$.

As illustrated, metadiscourse is not about grammatical correctness, phraseology, or paragraph structure. Nevertheless, it can make a big difference between mature and immature writing, or a paper that is accepted for publication and one that is not. If learning to write academic and research genres represents a problem for students, learning to write those genres in a foreign language is an even bigger challenge. Many factors should be taken into account in the teaching and learning of writing in an L2, and one that is beyond formal and superficial features is awareness of genre, register, cultural, and disciplinary variation in texts. It is actually those factors that might determine the appropriate use of metadiscourse in L2 academic writing (Ädel, 2006).

Both Swales' and Hyland's proposals for analyzing discourse have the power to inform teaching and learning processes within the realm of academic writing. There are at least two respects in which language teachers and learners can benefit from them. First, they help learners not only to use language but to reflect on language. As put by McCarthy et al. (2010, p. 53), by raising students' awareness on their own use of language, they "learn to attend to the different strands of patterning in discourse and to focus on those contexts and linguistic strategies that are most immediately relevant”. Second, teachers can design materials aimed at assisting students in their training and development of academic writing. It would actually be quite advantageous for students to analyze themselves samples of genres that they wish to master the ability to write. As suggested by Rose and Martin (2012) in their learning cycle, students writing their own texts (independent construction) should be preceded by text analysis with the help of teachers (joint deconstruction) and writing texts with the help of teachers (joint construction).

\section{Discourse Studies and Translation}

Another important branch of applied linguistics that benefits from discourse studies is translation. A notable translation theorist from the last century that considered translation as a branch of comparative linguistics was J. C. Catford. For him, translation was defined as "the replacement of textual material in one language (SL) by

\footnotetext{
${ }^{2}$ Note that this paragraph lacks elements of self mention and engagement. Actually, the use of first and second grammatical person is typically limited in research articles. However, parenthetical brackets (especially, the three first couples) could be considered a kind of engagement marker, since they are a way to involve the reader in a "by the way" fashion.
} 
equivalent textual material in another language (TL)" (Catford, 1965, p. 20). In his book, this definition is the starting point of a discussion that highlights two important aspects. One is that he does not refer to the replacement of one text in a SL by another text in a TL, but to the replacement of textual material. As he points out, this means that it is usually impossible to translate the entirety of a text using equivalences from the TL. When there are no equivalences, adaptations are called on in the translation process.

The other aspect is the use of the term "equivalence”, which is "the conceptual basis of translation" (House, 1997, p. 25) and whose nature and conditions should be defined by translation theory (Catford, 1965). Because total replacement is not possible, it is then important to identify the elements that do possess equivalences in a TL. From a systemic functional perspective, Halliday (2001, p. 15) suggests that the nature of equivalence can be found within the parameters of language itself, and that it "could be assigned differential values according to the specific conditions attaching to a particular instance of translation”. For example, between a source text and a target text, there could be equivalences at the level of phonology, lexicogrammar, and discourse semantics. Depending on "the specific conditions of particular translation instances", the value of each level varies from text to text. So, in poetic translation, phonological equivalence is highly valued; in typological linguistic glosses, lexicogrammatical equivalence is; and, in probably the majority of texts, discourse semantic equivalence possesses the highest value. In the following, I will illustrate two methods that can be drawn on to show discourse semantic equivalence between a source and a target text, namely, rhetorical structure (as proposed by Mann \& Thompson, 1988) and thematic structure (as proposed by Halliday, 1994).

Mann and Thompson's rhetorical structure theory (1988) is a theory of text organization that explains cohesion in terms of discourse relations held by the different parts of texts. From this view, if all sentences in a text "hang-together", it is because they relate to each other in particular ways. Of course, this is clear when writers use so-called "transition words" to make the connections explicit, but when they are not used, that does not necessarily mean that sentences are non-sequiturs. Consider the following abstract in Spanish, taken from an article of the Mexican journal Estudios de Lingüística Aplicada (Errico, 2015) (sentences have been numbered for convenience of reference).

[1] Este artículo reflexiona sobre la vitalidad del español científico-académico, que está en retroceso debido, entre otras razones, al prestigio creciente del que disfrutan las publicaciones en inglés. [2] Esta asimetría plantea una situación de desventaja potencial para los estudiosos hispanos y en general socializados en culturas no angloparlantes que, para ver reconocido su trabajo, tienen que realizar el esfuerzo adicional de escribir en una lengua extranjera y aun así corren el riesgo de ver rechazados sus trabajos por razones distintas a la calidad de su investigación. [3] Un paliativo a esta desigualdad podría ser una mayor tolerancia por parte de los agentes intermediarios en el proceso de publicación a las incorrecciones o patrones retórico-discursivos en los textos procedentes de culturas con escritura diferentes a la anglosajona. [4] Otra vía podría ser impulsar las publicaciones de acceso abierto, que permiten librar la estricta selección de los índices bibliométricos, muy sesgada hacia las publicaciones en inglés.

Between sentence [1] and [2], there is no transition word, but, as mentioned above, there has to exist a particular relationship. Following Mann and Thompson (1988, p. 73), there would be an Elaboration relationship, where sentence [1] is nuclear ( $\mathrm{N}$ ) and [2] is satellital (S), meaning that $\mathrm{S}$ is subordinated to $\mathrm{N}$. Consider Mann and Thompson's definition of Elaboration (1988, p. 73): "S presents additional detail about the situation or some element of subject matter which is presented in $\mathrm{N}$ or inferentially accessible in N". Thus, it could be said that sentence [2] gives additional detail about the situation presented in sentence [1]. Now, the host journal of the 
article requires authors to submit the abstract both in Spanish and English. Because the article is in Spanish, we can assume that the abstract in English is the target text and the one in Spanish is the source text. Consider now the abstract in English:

[1] This article analyzes the vitality of Spanish as a means of scientific-academic communication, which is currently losing ground due to the increasing prestige of publishing in English. [2] As a result, Spanish-speaking and in general non-Anglophone scholars are potentially placed at a disadvantage, since in order to have their research published, they are required to make the extra effort of publishing in a foreign language; hence, they face the risk of failure for reasons other than the quality of their research. [3] A solution to this inequality might be an increased tolerance of publishing brokers towards either language errors in texts and/or argumentative-rhetorical patterns belonging to non-Anglophone writing cultures. [4] Another alternative could be furthering open access journals, which allow bypassing the strict selection of bibliometric indexes, which is overly biased in favor of publications written in English.

As can be observed, this version has a transition phrase at the beginning of sentence [2]. This phrase (As a result), clearly signals a rhetorical relation of result, defined by Mann and Thompson (1988, p. 75) as one where "N presents a situation that caused the situation presented in S". Therefore, the translation strategy affects the rhetorical analysis of the text, and if the analysis of the discourse researcher suggests that the source text and target text have different rhetorical structures, it is likely that readers in general process those two texts differently (da Cunha \& Iruskieta, 2010). Figure 6 presents the rhetorical analysis of the texts.

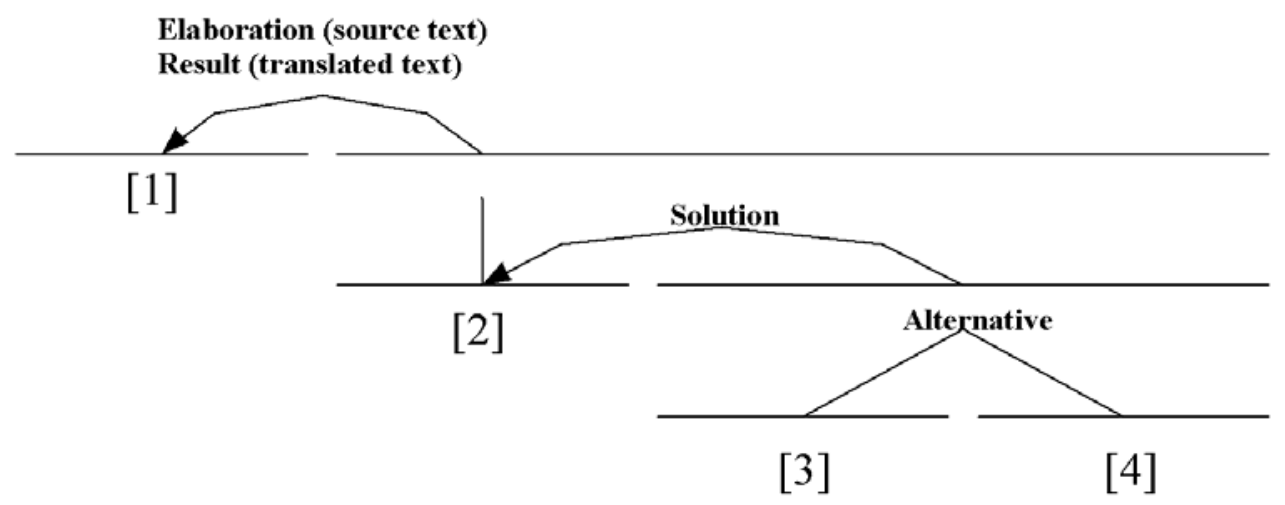

Figure 6. Rhetorical structure of the texts.

As can be observed, the only translation shift is the one discussed above. With the aim of rhetorical structure theory, analysts are able to discern discourse semantic equivalences and shifts in translation. One possible significant contribution could be in the field of machine translation. In fact, there have been attempts to develop computer programs capable of analyzing rhetorical structure automatically based on banks of manmade analyses (e.g., da Cunha, San Juan, Torres-Moreno, Cabré, \& Sierra, 2012; da Cunha, San Juan, Torres-Moreno, Lloberese, \& Castellóne, 2012). If a machine translation system had as its basis the replacement of equivalent rhetorical structures between a source and a translated text, the end products would likely be more satisfactory than they are at present.

The other discourse analysis method to be illustrated here is thematic structure (as proposed by Halliday, 1994), which has to do with textual meaning (already briefly described in this paper). Thematic structure refers to the flow of information and the method of development of thematic and rhematic elements in a text. According to 
Halliday (1989), themes can be of three types, namely, experiential, interpersonal, and textual. Experiential themes are topical elements such as participants, processes, and circumstances; interpersonal themes are elements with mood or modality meanings such as adjuncts, interrogative pronouns, vocatives, and projecting clauses; textual themes are transition words and phrases. Of the three types of theme, only experiential ones appear obligatorily in sentences. Consider the following introductory paragraph of a medical research article, taken from the Journal of the American College of Cardiology (Jhund, Davie, \& McMurray, 2001a):

[1] Intravenous furosemide is commonly administered to patients with acute heart failure to relieve pulmonary congestion through diuresis.

[2] However, it has been observed for some time that symptomatic relief occurs in these patients before the onset of diuresis.

[3] This effect is believed to result from an independent venodilator action, which precedes the diuretic effect of furosemide.

[4] This venodilator response to furosemide is inhibited by the cyclooxygenase inhibitor indomethacin.

[5] It is believed, therefore, that venodilation is brought about through the release of local prostaglandins.

In this text, experiential themes have been marked in bold, interpersonal ones in italics, and textual ones with underlining. Focusing on experiential themes, it can be seen that, in subsequent sentences, some rhematic elements become thematic, and some thematic elements are reiterated. For instance, in sentence [1] the rhematic verb relieve becomes thematic in [2], in its nominal form (relief). Then, the clause in [2] symptomatic relief occurs in these patients before the onset of diuresis is used as theme in [3], also in a nominal form (This effect). Later, the rhematic nominal group in [3] an independent venodilator action, which precedes the diuretic effect of furosemide becomes thematic in [4] (This venodilator response to furosemide), and is then reiterated as theme in [5] (venodilation). This medical article was translated into Spanish and published in the Mexican edition of the same journal (Jhund, et al., 2001b). Here is the translation of the introductory paragraph:

[1] La administración intravenosa de furosemida es frecuente en los pacientes con insuficiencia cardíaca aguda, con objeto de aliviar la congestión pulmonar mediante diuresis.

[2] Sin embargo, se ha observado desde hace algún tiempo que, en estos pacientes, el alivio sintomático es anterior al inicio de la diuresis.

[3] Suponemos que este efecto es el resultado de una acción venodilatadora independiente que antecede al efecto diurético de la furosemida.

[4] Esta respuesta venodilatadora frente a la furosemida es inhibida por el inhibidor de la ciclooxigenasa indometacina.

[5] Por tanto, suponemos que la venodilatación se debe a la liberación local de prostaglandinas.

Notice first that the translator nominalized the clase Intravenous furosemide is commonly administered of sentence [1] as La administración intravenosa de furosemida. However, this change does not affect the thematic development of the information. Therefore, although there was a shift at the level of lexicogrammar, there is discursive equivalence. On the other hand, in sentence [2], the translator put the circumstance en estos pacientes as experiential theme, instead of el alivio sintomático, as in the source text. Previously we observed that, in the 
original text, the thematic element relieve/relief went from being a rhematic element in [1] to a thematic one in [2]. Now, in the translated text, the element pacientes also goes from being a rhematic element in [1] to a thematic element in [2]. Hence, although the element in question has shifted in relation to the original, the same information development process occurs.

With this analysis, we have seen that information structure is a method through which researchers can determine the existence of discursive equivalence between a source and a translated text, but also one that translators and translation practitioners can take advantage of. Translators deal with language, and if they are trained to become good discourse analysts, their translation strategies will be better informed, resulting in better texts.

\section{Final Remarks}

In this document, I have discussed the importance of discourse studies in linguistics in general, in language teaching, and in translation. Because with discourse people do things, it is fundamental to take a social perspective when analyzing language beyond the sentence and language within context. This enables us to realize the functional nature of language, including the aspects to focus on when dealing with written or spoken discourse, and when dealing with specific discourse genres. In the academic context, it has been shown that there are discourse analysis models such as Swales' (1990) and Hyland's (2005) that are useful in the teaching and learning of research and scholastic genres. In addition, other discourse models like Mann and Thompson’s (1989) and Halliday's (1989) can be used to determine discursive equivalence between a source text and its translation. Those are only a few models from the many more that have been developed in the last 30 years or so. It was only by considering authentic texts performed in authentic contexts as valuable research data that linguists have been able to develop all those valuable discourse models and theories.

\section{References}

Ädel, A. (2006). Metadiscourse in L1 and L2 English. Amsterdam: Benjamins.

Allen, N. B. (1968). The two parts of “Othello”. In K. Muir (Ed.), Shakespeare survey 21: Othello (pp. 13-30). Cambridge: Cambridge University Press.

Bakhtin, M. (1986). Speech genres and other late essays. C. Emerson and M. Holquist (Eds.). V. W. McGee (Trans.). Austin: University of Texas Press.

Bhatia, V. K. (1997). Genre-mixing in academic introductions. English for Specific Purposes, 16(3), 181-197.

Bazerman, C. (1997). The life of genre, the life in the classroom. In W. Bishop and H. Ostrom (Eds.), Genre and writing: Issues, arguments, alternatives (pp. 19-26). Portsmouth: Boynton \& Cook.

Berns, M., \& Matsuda, P. K. (2010). Applied linguistics. In M. Berns (Ed.), Concise Encyclopedia of Applied Linguistics (pp. 3-13). Amsterdam: Elsevier.

Brown, G., \& Yule, G. (1983). Discourse analysis. Cambridge: Cambridge University Press.

Catford, J. C. (1965). A linguistic theory of translation: An essay in applied linguistics. Oxford: Oxford University Press.

Coffin, C., Hewings, A., \& North, S. (2012). Arguing as an academic purpose: The role of asynchronous conferencing in supporting argumentative dialogue in school and university. Journal of English for Academic Purposes, 11(1), 38-51.

Da Cunha, I., \& Iruskieta, M. (2010). Comparing rhetorical structures in different languages: The influence of translation strategies. Discourse Studies, 12(5), 563-598.

Da Cunha, I., San Juan, E., Torres-Moreno, J. M., Cabré, M. T., \& Sierra, G. (2012). A symbolic approach for automatic detection of nuclearity and rhetorical relations among intra-sentence discourse segments in Spanish. In A. Gelbukh (Ed.), Computational linguistics and intelligent text processing: 13th international conference, CICLing 2012 (part 1) (pp. 462-474). Berlin: Springer. 
Da Cunha, I., San Juan, E., Torres-Moreno, J. M., Lloberese, M., \& Castellóne, I. (2012). DiSeg 1.0: The first system for Spanish discourse segmentation. Expert Systems With Applications, 39(2), 1671-1678.

Dreyfus, S. J., Humphrey, S., Mahbob, A., \& Martin, J. R. (2016). Genre pedagogy in higher education: The SLATE project. Basingstoke: Palgrave Macmillan.

Errico, E. (2015). El español frente al inglés en la comunicación científico-académica: ¿Una lengua que goza de buena salud? Estudios de Lingüística Aplicada, 33(62), 223-241.

Fryer, D. L. (2012). Analysis of the generic discourse features of the English-language medical research article: A systemic-functional approach. Functions of Language, 19(1), 5-37.

Gledhill, C. (2000). The discourse function of collocation in research article introductions. English for Specific Purposes, 19(2), 115-135.

Halliday, M. A. K. (1989). Spoken and written language. Oxford: Oxford University Press.

Halliday, M. A. K. (1994). An introduction to functional grammar (2nd ed.). London: Arnold.

Halliday, M. A. K. (1997/2004). On the grammar of scientific English. In J. J. Webster (Ed.), The language of science (Collected works of M. A. K. Halliday, Vol. 5) (pp. 181-198). London: Continuum.

Halliday, M. A. K. (2001). Towards a theory of good translation. In E. Steiner and C. Yallop (Eds.), Exploring translation and multilingual text production: Beyond content (pp. 13-18). Berlin: Mouton.

Halliday, M. A. K., \& Hasan, R. (1989). Language, context, and text: Aspects of language in a social-semiotic perspective (2nd ed.). Oxford: Oxford University Press.

Halliday, M. A. K., \& Matthiessen, C. M. I. M. (1999). Construing experience through meaning: A language-based approach to cognition. London: Routledge.

Halliday, M. A. K., \& Matthiessen, C. M. I. M. (2014). Halliday’s introduction to functional grammar. London: Routledge.

Harris, Z. (1952). Discourse Analysis. Language, 28(1), 1-30.

Harris, Z. (1959/1970). Linguistic transformations for information retrieval. In Papers in structural and transformational linguistics (pp. 458-471). Dordrecht: Springer.

House, J. (1997). Translation quality assessment: A model revisited. Tübingen: Narr.

Hyland, K. (2004). Genre and second language writing. Michigan: The University of Michigan Press.

Hyland, K. (2005). Metadiscourse: Exploring interaction in writing. London: Continuum.

Hyland, K. (2009). Academic discourse: English in a global context. London: Continuum.

Hymes, D. (1972). On communicative competence. In J. B. Pride and J. Holmes (Eds.), Sociolinguistics (pp. 269-293). Harmondsworth: Penguin Books.

Jhund, P. S., Davie, A. P., \& McMurray, J. J. V. (2001a). Aspirin inhibits the acute venodilator response to furosemide in patients with chronic heart failure. Journal of the American College of Cardiology, 37(5), 1234-1238.

Jhund, P. S., Davie, A. P., \& McMurray, J. J. V. (2001b). La aspirina inhibe la respuesta venodilatadora inducida por la furosemida en los pacientes con insuficiencia cardíaca crónica. Journal of the American College of Cardiology (Edición mexicana), 10(6), 257-262.

Jordan, R. R. (1997). English for academic purposes: A guide and resource book for teachers. Cambridge: Cambridge University Press.

Mann, W., \& Thompson, S. (1988). Rhetorical structure theory: Toward a functional theory of text organization. TEXT, 8(3), 243-281.

Markee, N. (2008). Toward a learning behavior tracking methodology for CA-for-SLA. Applied Linguistics, 29(3), 404-427.

Martin, J. R. (1997/2012). Register and genre: Modelling social context in functional linguistics-Narrative genres. In Z. Wang (Ed.), Genre studies (Collected works of J. R. Martin, Vol. 3) (pp. 187-221). Shanghai: Shanghai Jiao Tong University Press.

Martin, J. R., \& Rose, D. (2007). Working with discourse: Meaning beyond the clause (2nd ed.). London: Continuum.

Martin, J. R., \& Rose, D. (2008). Genre relations: Mapping culture. London: Equinox.

Matthiessen, C. M. I. M., Teruya, K., \& Lam, M. (2010). Key terms in systemic functional linguistics. London: Continuum.

McCarthy, M., Matthiessen, C. M. I. M., \& Slade, D. (2010). Discourse analysis. In N. Schmitt (Ed.), An introduction to applied linguistics (2nd ed.) (pp. 53-69). London: Routledge.

Poole, D. (2010). Discourse analysis and applied linguistics. In R. B. Kaplan (Ed.), The Oxford handbook of applied linguistics (pp. 73-84). Oxford: Oxford University Press.

Rose, D., \& Martin, J. R. (2012). Learning to write, reading to learn: Genre, knowledge and pedagogy in the Sydney School. London: Equinox. 
Samraj, B. (2002). Introductions in research articles: Variations across disciplines. English for Specific Purposes, 21(1), 1-18. Swales, J. M. (1981). Aspects of article introductions. Birmingham: Aston University.

Swales, J. M. (1990). Genre analysis: English in academic and research settings. Cambridge: Cambridge University Press. Swales, J. M. (2004). Research genres: Explorations and applications. Cambridge: Cambridge University Press.

Thompson, G., \& Thetela, P. (1995). The sound of one hand clapping: The management of interaction in written discourse. TEXT, 15(1), 103-127. 